\title{
Carbon isotopic composition of fossil leaves from the Early Cretaceous sediments of western India
}

\author{
S Chakraborty ${ }^{1, *}$, B N JAna ${ }^{2}$, S K Bhattacharya ${ }^{3}$ and I Robertson ${ }^{4}$ \\ ${ }^{1}$ Indian Institute of Tropical Meteorology, Dr. Homi Bhabha Road, Pune 411 008, India. \\ ${ }^{2}$ Birbal Sahni Institute of Palaeobotany, Lucknow 226 00\%, India. \\ ${ }^{3}$ Physical Research Laboratory, Ahmedabad 380 009, India. \\ ${ }^{4}$ Department of Geography, Swansea University, Swansea, UK. \\ *e-mail: supriyoc@gmail.com
}

\begin{abstract}
Stable carbon isotope analysis of fossil leaves from the Bhuj Formation, western India was carried out to infer the prevailing environmental conditions. Compression fossil leaves such as Pachypteris indica, Otozamite kachchhensis, Brachyphyllum royii and Dictyozamites sp. were recovered from three sedimentary successions of the Bhuj Formation, Early Cretaceous in age. A chronology was established based on faunal assemblage and palyno-stratigraphy and further constrained by carbon isotope stratigraphy. The three sampling sites were the Karawadi river bank near Dharesi; the Chawad river bank near Mathal; and the Pur river section near Trambau village in Gujarat. The Dharesi sample was also analyzed to investigate intra-leaf $\delta^{13} \mathrm{C}$ variability. The mean $\delta^{13} \mathrm{C}$ of the leaf was $-24.6 \pm 0.4 \%$ o which implied negligible systematic change along the leaf axis. The Mathal sample was fragmented in nature and showed considerable variation in carbon isotopic composition. The Trambau sample considered to be the oldest, dating to the middle of Aptian ( $c a .116 \mathrm{Ma}$ ), shows the most depleted value in $\delta^{13} \mathrm{C}$ among all of them. The overall $\delta^{13} \mathrm{C}$ trend ranging from mid Aptian (ca. $116 \mathrm{Ma}$ ) to early Albian (ca. $110 \mathrm{Ma}$ ) shows a progressive increase in $\delta^{13} \mathrm{C}$ from -26.8 to $-20.5 \%$. Based on these measurements the carbon isotopic composition of atmospheric carbon dioxide of the Aptian-Albian period is estimated to be between -7.4 and $-1.7 \%$. The ratio of the partial pressure of carbon dioxide in leaf to that of the ambient atmosphere calculated based on a model is estimated to be similar to that of the modern plants. This indicates that the Early-Cretaceous plants adapted to the prevailing high carbon dioxide regime by increasing their photosynthetic uptake.
\end{abstract}

\section{Introduction}

The Earth has undergone several major environmental changes throughout the geological time. One of the most significant changes in the ocean atmosphere system that took place during the Cretaceous had imprints in both terrestrial and marine environments (Jemkyns 1980; Bralower et al 1994; Crane et al 1995; Littler et al 2011). Geochemical, paleobotanical and paleontological studies have provided valuable information about the environmental conditions of the Cretaceous. For example, the study of stomatal density in plant fossils provide an important means to estimate the past $\mathrm{pCO}_{2}$ conditions (Retallack 2001). This has also been corroborated by stable carbon isotopic analysis of phytoplankton and pedogenic carbonates (Royer et al 2001). However, large uncertainties exist in

Keywords. Carbon isotopes; plant fossil; Cretaceous; Kachchh; $\mathrm{pCO}_{2}$. 
quantifying one of the most important atmospheric parameters, the isotopic composition of carbon dioxide in the Cretaceous atmosphere. It is believed that $\delta^{13} \mathrm{C}$ of atmospheric $\mathrm{CO}_{2}$ during the Cretaceous was similar to the pre-industrial level of around $-6.5 \%$ o (Cerling 1991; Leuenberger et al 1992; Francey et al 1999; McCarroll and Loader 2004). But analysis of fossil plants indicates a somewhat enriched value. During the Aptian, Gröcke (2002) observed a large range in carbon isotopic composition of atmospheric $\mathrm{CO}_{2}$ that varied between 0.5 and $-10 \%$ and estimated an average $\delta^{13} \mathrm{C}$ of atmospheric $\mathrm{CO}_{2}$ in the order of $-3.0 \%$. Since no single proxy record is able to provide this information with sufficient temporal and spatial resolution, it is thus essential to analyze fossil plants at various stratigraphic levels and at different geographic regions for a better estimate of atmospheric carbon isotopic composition. The study of fossil plant or plant mega fossil has certain advantages over the use of bulk terrestrial organic matter (TOM) that is widely used to establish correlation between the marine and terrestrial carbon cycle events through geological time (Grocke et al 2005). For example, the TOM can be sourced from a variety of floral components with varying abundances between samples and the TOM may be composed of floral components from different environments and thus varying isotopic signatures (op cit.). Plant mega-fossil representing a single species does not suffer from such limitations. It is also well established that the fossil plants typically retain their isotopic compositions (Degens 1969; Nambudiri et al 1978; Rigby et al 1981; Aucourt and Hillaire-Marcel 1993; Bocherens and Marootti 1998). So it is quite likely that the analysis of fossil plants from the Indian subcontinent would be useful in enhancing our understanding of the ancient atmospheric compositions, since carbon fixed by land plants reflects carbon isotopic fluctuations of atmospheric $\mathrm{CO}_{2}$, and consequently, the isotopic behaviour of the ocean-atmosphere system (Hasegawa et al 2003). The Indian fossil plants have been extensively studied by paleobotanists to investigate the past vegetational and environmental conditions (Seward and Sahni 1920; Sahni 1928; Bose and Roy 1961; Roy 1967; Bose and Kasat 1972; Bose and Banerji 1984). But to our knowledge, no isotopic analysis of fossil leaves has ever been undertaken, especially from the Kachchh basin in Gujarat which is known to be a rich source of well preserved plant fossils belonging to the Mesozoic (Bose and Kasat 1972; Bose and Banerji 1984). Though in this context it may be mentioned that the isotopic analysis of benthic foraminifera from Kachchh helped to quantify the Palaeogene temperature that ranged between $22^{\circ}$ and $32^{\circ} \mathrm{C}$ in this region (Saraswati and Ramesh 1992; Saraswati et al 1993).

Leaf carbon isotope composition varies by $1-$ $2 \%$ depending upon several factors including irradiance, height and aspect (Leavitt and Long 1986; Lockheart et al 1998; Heaton 1999; Turney et al 2002), but the intra-leaf carbon isotopic variability is no greater than that observed for bulk plant material. In this article, we report the preliminary observations on the carbon isotopic analysis of the compression fossil leaves from the Kachchh basin in Gujarat and discuss its implications in understanding the paleoenvironmental conditions prevailing during the Early Cretaceous.

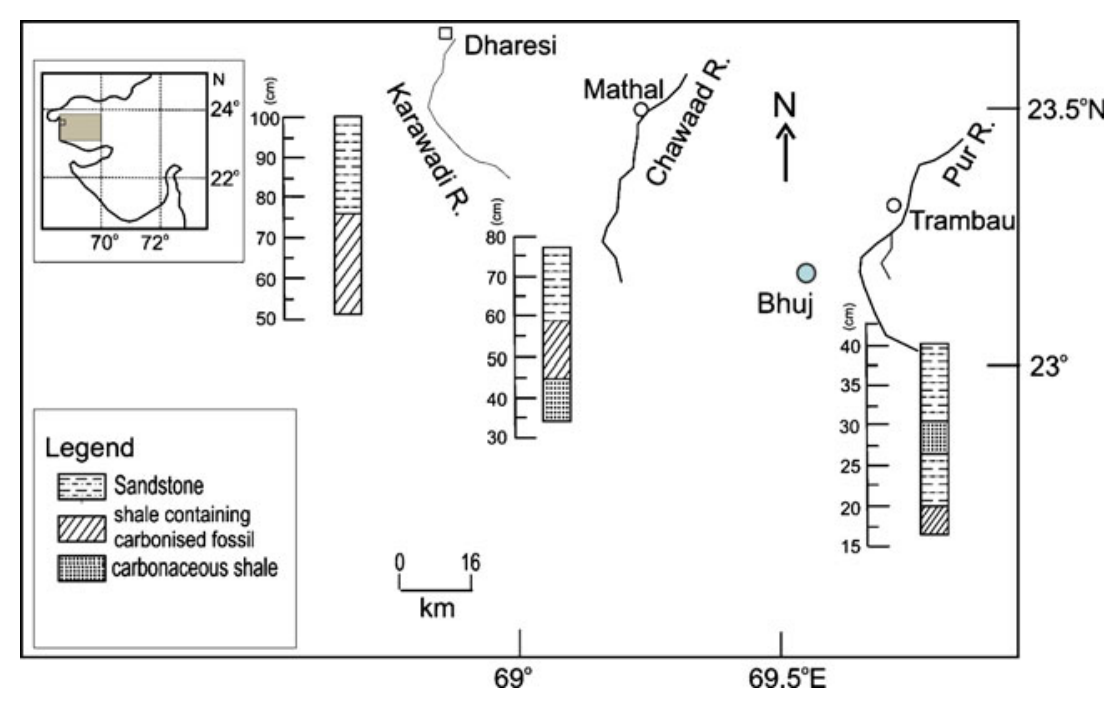

Figure 1. The sampling sites in the Kachchh basin of Gujarat. The grey area in the inset shows the sample location. Dharesi is marked by an open square. Other two sites, namely Mathal and Trambau are shown in the enlarged portion. The vertical scale for each of the site is also shown. 


\section{Materials and method}

The plant mega fossils were collected from three localities belonging to the north western region of the Kachchh basin in Gujarat (figure 1). The first site is located near village Dharesi $\left(23^{\circ} 41^{\prime} \mathrm{N}\right.$, $\left.68^{\circ} 51^{\prime} \mathrm{E}\right)$ and the other two are from Mathal village of the Chawaad river section $\left(23^{\circ} 30^{\prime} \mathrm{N}\right.$, $69^{\circ} 15^{\prime} \mathrm{E}$ ) and Trambau village of the Pur river section $\left(23^{\circ} 19^{\prime} \mathrm{N}, 69^{\circ} 44^{\prime} \mathrm{E}\right)$ (figure 1$)$. All of the

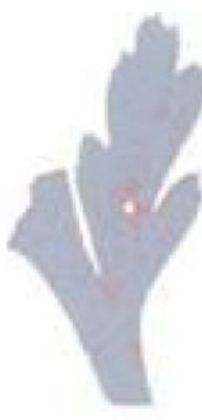

(a)

(b)
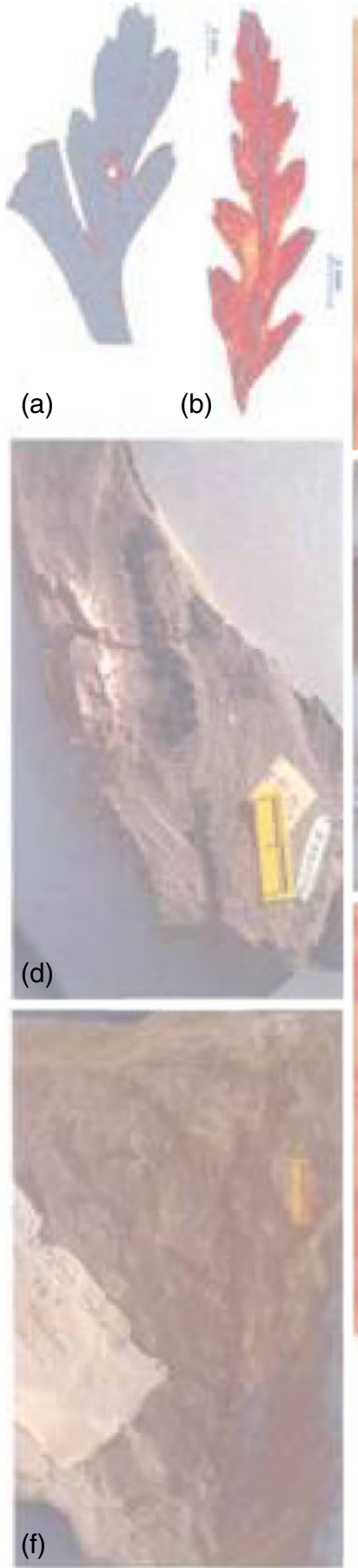
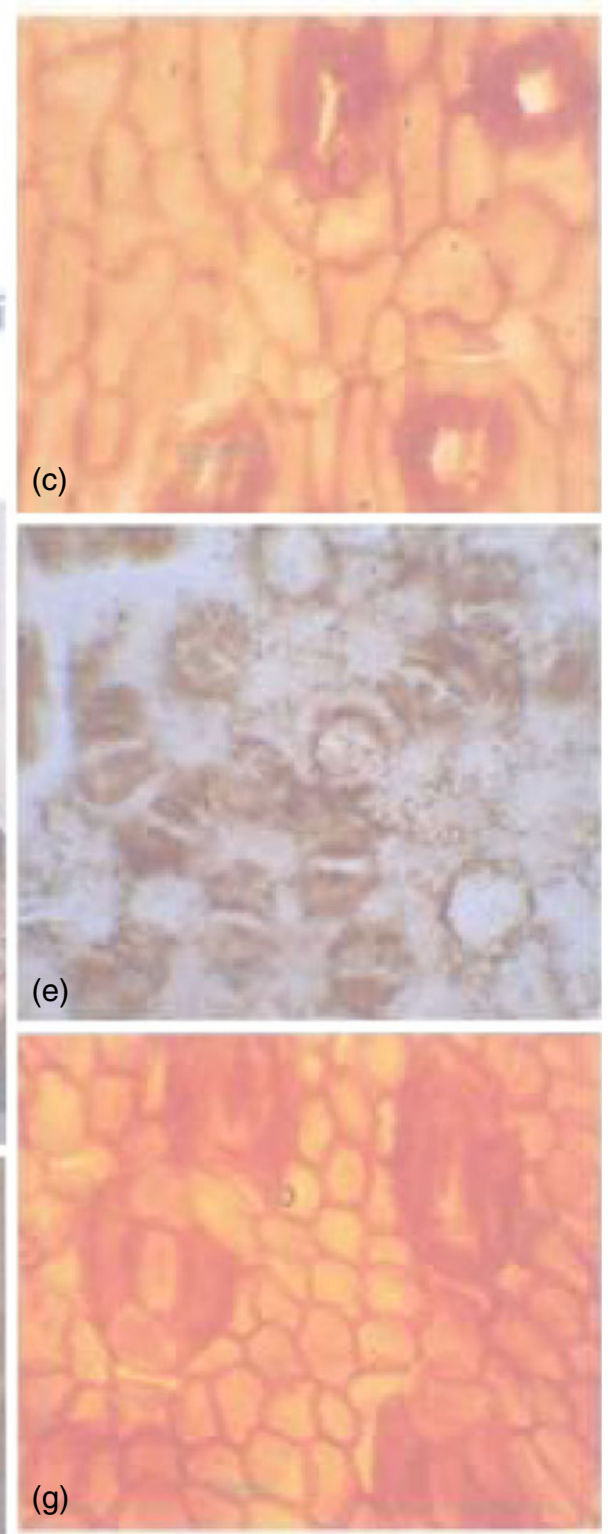

Figure 2. The fossil specimens used in this study. (a and b) A small twig of Pachypteris indica (No. B.S.I.P. 1/2679 C); at initial and final stages of maceration respectively; (c) a portion of stomatiferous surface of P. indica (No. B.S.I.P. 90/24111); (d) Ottozamites kachchhensis - preserved on bedrock. The missing portion at the middle of the fossil specimen was used for stable isotopic analysis. (e) Magnified part of stomatiferous surface of O. kachchhensis; (f and $\mathbf{g}$ ) Brachyphyllum royii. (f) Branched leafy twigs of $B$. royii (No. B.S.I.P 32262) and (g) a magnified part of stomatiferous portion of $B$. royii (No. B.S.I.P. 84/2089c-1); (h) a leafy potion of Dictyozamites sp. (No. B.S.I.P. 29/6235), and (i) shows a part of stomatiferous pinnule surface (No. B.S.I.P. 29/62635-1); (j) leafy twigs of Pagiophyllum morrissii (No. B.S.I.P. 71/2679); and (k) stomatiferous portion of P. morrissii (No. B.S.I.P. 38/2676-1). 

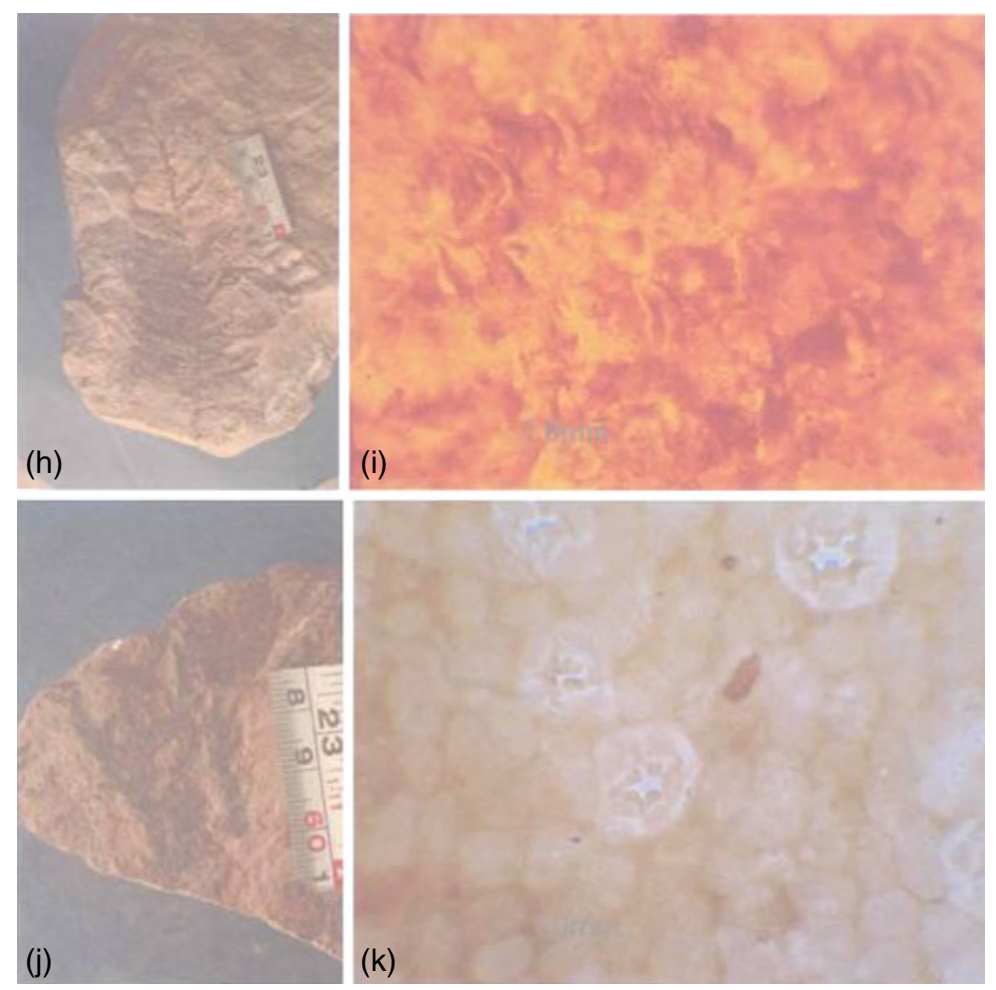

Figure 2. (Continued).

sites show well exposed mid-to-lower Cretaceous sedimentary successions. The sedimentary deposits mainly consist of gravel, sandstone and carbonaceous shale.

The Dharesi site is situated about $120 \mathrm{~km}$ northwest of the town of Bhuj and $40 \mathrm{~km}$ east of the lake, Narain Sarovar. The fossiliferous section under study was exposed on the northern bank of the river Karawadi and located ca. $1.5 \mathrm{~km}$ northwest of Dharesi village. One mega fossil was collected from this site that yielded almost entire portion of a leaf. A total of eight samples were collected from the other two sections; these were fragments of different portions of fossil leaves belonging to four genera. The physical characteristics of the fossils as well as the taphonomic analysis (Bose and Banerji 1984) suggest that the deposits were original leaf carbon and no secondary deposits were present.

The village Trambau is situated ca. $11 \mathrm{~km}$ northeast of the town of Bhuj. The fossiliferous beds in this area are exposed mainly along the northern and southern banks of the Pur River. The carbonized fossils were recovered from a section that was $2.5 \mathrm{~km}$ northwest of the village Trambau.

The Mathal and Trambau samples are relatively older than the Dharesi sample. The geologic timescale in this area was estimated from palynostratigraphy and faunal assemblages (Bose and
Banerji 1984). Three to four lithofacies were found in these sections. For example, Dharesi is characterized by sandstone and carbonaceous shale, both containing fossil leaves. Other two sections have poorly stratified sandstone facies, carbonaceous shale and siltstone/claystone facies dominated by carbonized organic matter.

Of these localities, well preserved compression fossils were mainly found at Trambau in Pur River site and Mathal in Chawad River site. On the contrary, the fossils from Dharesi are relatively ill preserved. This particular fossiliferous section (Dharesi) is more weathered. But the fossils of Trambau and Mathal sections are less weathered and are overlain by huge layers of other strata in Trambau. Figure 2 shows the fossil specimens used in this study; (a) and (b) show a small twig of Pachypteris indica at initial and final stages of maceration; other images from (c) to (k) have been described in the figure.

For isotopic analysis the fragmentary organic matter was carefully separated from the host rock by gently scraping with knife and scalpel. The samples were treated according to the methodology of Gröcke et al (1999) but with minor modifications. They were treated with dilute $(2 \mathrm{M})$ hydrochloric acid to remove carbonates and then with mild alkali and acid in sequence. The samples were thoroughly rinsed with de-ionized water and dried overnight in an oven $\left(40^{\circ} \mathrm{C}\right)$. 
The leaf sample (ca. $10 \mathrm{mg}$ ) was combusted at a temperature of $800^{\circ} \mathrm{C}$ in a quartz tube attached to a vacuum system (dimensions; $150 \mathrm{~mm}$ long $\times$ $8 \mathrm{~mm}$ bore) in the presence of copper (II) oxide (500 mg) and silver wool for approximately 3 hours (Sofer 1980; Minagawa et al 1984). Following the cryogenic separation of water, $\mathrm{CO}_{2}$ was dynamically transferred to a calibrated volume to determine the yield and finally collected and sealed in a glass ampoule. Subsequently, the ampoules were taken to the Physical Research Laboratory, Ahmedabad for mass spectrometric measurements on a Europa GEO 20-20 isotope ratio mass spectrometer. The isotopic values were reported in $\delta$ notation, relative to VPDB and expressed in permil (\%o). The measurement precision based on the replicate analysis of a standard was $0.1 \%$ while the overall analytical precision was $0.33 \%$. In most cases, the small sample sizes prevented the repeat analysis of leaf material.

To check the accuracy of the method, the IAEA $\mathrm{C}_{3}$ cellulose international standard was also analyzed in the same way. The mean $\delta^{13} \mathrm{C}$ value of $-25.03 \pm 0.33 \%$ o $n=10$ was in good agreement with the consensus value of $-24.91 \pm 0.49 \%$ o (3- $\sigma$ error) (Rozanski 1991; Rozanski et al 1992) and similar to other reported values; $-24.60 \pm 0.10 \%$, $n=50$ (Knöller et al 2005) and the recently recommended value of $-24.72 \%$ (Coplen et al 2006).

Table 1. Dharesi sample showing the intra-leaf variability in $\delta^{13} C$.

\begin{tabular}{lc}
\hline Leaf portion & $\delta^{13} \mathrm{C}$ \\
& $(\% 0)$ \\
\hline Top & -24.8 \\
& -24.9 \\
Middle & -24.8 \\
& -24.7 \\
& -24.8 \\
Base & -24.2 \\
\hline
\end{tabular}

\section{Results}

The isotopic data of the Dharesi sample are given in table 1, while table 2 compiles the same for all three sites. Table 1 shows the intra-leaf variability in $\delta^{13} \mathrm{C}$.

The $\delta^{13} \mathrm{C}$ of the base of the leaf is found to be slightly enriched $(-23.9 \%$ ) relative to its top $(-24.8 \%$ ) . The total variation is $c a .1 .0 \%$ and the mean value is $-24.58 \pm 0.38 \%$ o $(n=7)$. It seems that the intra-leaf variability in $\delta^{13} \mathrm{C}$ of fossil plants from this region is about $1 \%$ and that the leaf samples represent $\mathrm{C}_{3}$ type of plant.

\section{Discussion}

In order to interpret the isotopic data it is essential to know whether there was any diagenetic alteration of the sample. Indirect evidence shows that diagenetic alteration was minimal in this case. Firstly the cellular details of these fossil leaves were carefully studied under microscope and no sign of alteration was found attesting excellent preservation. Secondly, the isotopic values obtained in these cases are in good agreement with that of the plants belonging to the same period from different geographical locations. For example, fossil plants analyzed from the Flat Rocks in Australia of the Aptian age gave a mean $\delta^{13} \mathrm{C}$ of $-23 \pm 1 \%$ o (Gröcke 1998). Popp et al (1989) reported $\delta^{13} \mathrm{C}$ of the terrestrial organic matter from the Cenozoic and Mesozoic to be around $-26 \%$. Cerling (1991) also used a value of $-26 \%$ for the organic matter for the Mesozoic. The carbon isotopic values of the fossil leaves obtained in this study are well within this range, which suggests that there was no significant diagenetic alteration of the leaf material.

There is considerable evidence which suggests that the ocean-atmosphere system underwent substantial changes during the Jurassic and Cretaceous time. Weissert and Erba (2004) presented a composite Late Jurassic-Early Cretaceous Tethyan

Table 2. The measurement of the carbon isotopic composition of the fossil plants studied in this paper.

\begin{tabular}{|c|c|c|c|c|}
\hline Laboratory no. & Sample identification & Sample site & $\delta^{13} \mathrm{C}(\% 0)$ & Approximate geological age \\
\hline Dharesi (mean) 84/2511 & Dictyozamites sp. & Dharesi & $-24.58 \pm 0.38$ & Early Albian (ca. $110 \mathrm{Ma}$ ) \\
\hline $82 / 2411 \mathrm{C}$ & Pachypteris indica & Mathal & -20.50 & \\
\hline $100 / 2411 B$ & Pachypteris indica & Mathal & -23.64 & \\
\hline $31 / 2891 \mathrm{~A}$ & Ottozamites kachchhensis & Mathal & -24.55 & \\
\hline $2 / 2679 \mathrm{C}$ & Pachypteris indica & Mathal & -26.02 & \\
\hline $135 / 2411 B$ & Pagiophylluim morrisii & Mathal & -26.19 & \\
\hline $90 / 2411 \mathrm{C}$ & Pachypteris indica & Mathal & -26.24 & \\
\hline $84 / 2411 \mathrm{C}$ & Pachypteris indica & Mathal & -26.63 & \\
\hline 32262 & Brachyphyllum royii & Trambau & -26.83 & Mid Aptian (ca. $116 \mathrm{Ma}$ ) \\
\hline
\end{tabular}


bulk carbonate carbon isotope plot that showed significant perturbations in the global carbon cycle. As mentioned earlier the approximate ages of these samples are made available from palynostratigraphy and faunal assemblages (Bose and Banerji 1984), that is Early Creataceous. Since Wiessert and Erba's (2004) bulk carbonate plot represents isotopic variation of the global carbon cycle, it is expected that the carbon isotopic composition of the contemporaneous vegetation would closely resemble this curve. So we compare the carbon isotopic values of our fossil leaves with the carbon isotopic record of the Tethyan bulk carbonate $\delta^{13} \mathrm{C}$ plot of Weissert and Erba (2004). Figure 3 shows the $\delta^{13} \mathrm{C}$ of the bulk carbonate (grey dots) and the fossil leaves (filled circles and rectangles). It is quite apparent from this figure that the pattern of variation of fossil leave $\delta^{13} \mathrm{C}$ is quite similar to that of the Tethyan bulk rock carbon isotopic variation. Based on this comparison, we further constrain the chronology of our fossil leaves that range from MidAptian to Early Albian. The approximate numerical ages of the end members were estimated to be $c a .116$ and $110 \mathrm{Ma}$ respectively based on the Weissert and Erba (2004) curve.

Table 2 shows the mean carbon isotopic values of the Dharesi sample as well as those of individual Mathal and Trambau samples. The samples have been arranged in sequence according to their approximate geological ages. The lowermost sample represents the Mid-Aptian ( $c a .116 \mathrm{Ma}$ ) while the

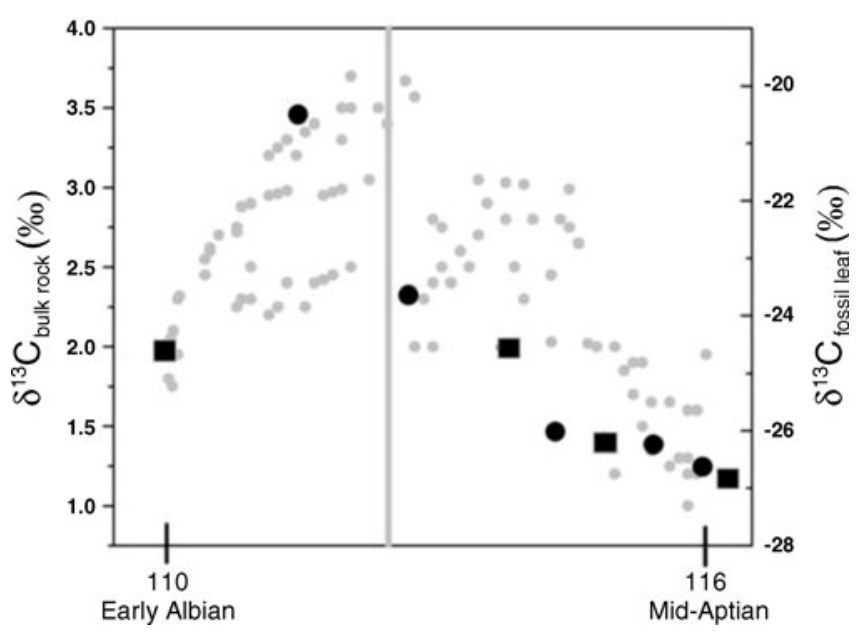

Figure 3. Comparison of the fossil leave $\delta^{13} \mathrm{C}$ with that of the bulk rock carbon that represented the ocean atmospheric changes of carbon cycle during the Cretaceous (Weissert and Erba 2004). The grey dots represent the bulk rock carbon isotopic composition while the filled circles and rectangles are that of fossil leaves $\delta^{13} \mathrm{C}$ of this study. The vertical axis on left shows the isotopic values of the bulk rock while the right axis represents that of the fossil leaf. The $\mathrm{x}$-axis is the geological age and the numerical values were based on the Weissert and Erba (2004) plot. The vertical grey line shows the boundary between Aptian and Albian. top sample (Dharesi) belongs to the Early Albian (ca. $110 \mathrm{Ma}$ ), approximately covering a period of 6 Ma. This exercise also helped us to assign an approximate age model of the individual samples based on their locations on the sedimentary horizon and assuming linear sedimentation rates. The lowermost sample shows the most ${ }^{13} \mathrm{C}$ depleted value of $-26.8 \%$ o whilst the topmost samples from Mathal is enriched by more than $6 \%$ having a $\delta^{13} \mathrm{C}$ value of $-20.5 \%$. Out of the eight samples, five samples (filled circle in figure 3) are $P$. indica, whilst the other three samples (filled rectangle) are Otozamite kachchhensis, Brachyphyllum royii, and Dictyozamites sp., respectively. It may be noted that the variance of $\delta^{13} \mathrm{C}$ of all the samples is significantly higher than the intra-leaf variability of $1 \%$ o (table 1) and hence the variability is unlikely due to inter species differences (Leavitt and Newbery 1992). There is, however, no direct evidence that this variability is due to environmental change and not due to taxonomy. However, from figure 3 we see that the pattern of carbon isotopic composition of all the species (except the Dharesi sample which comprises many fragments of a single leaf) and the pattern of $\delta^{13} \mathrm{C}$ variation of $P$. indica only, are more or less the same. Since $P$. indica is a single species and hence its isotopic values would be affected only by environmental parameters, our interpretation will not be affected even if the other three samples (Otozamite kachchhensis, Brachyphyllum royii, and Dictyozamites sp.) show species dependent carbon isotopic variability.

The carbon isotopic composition of $\mathrm{C}_{3}$ plants $\left(\delta^{13} \mathrm{C}_{\text {plant }}\right)$ is controlled by the concentration and $\delta^{13} \mathrm{C}$ values of atmospheric carbon dioxide, stomatal conductance and the carbon assimilation rate according to the following relation (Vogel 1980; Farquhar et al 1982a):

$$
\delta^{13} \mathrm{C}_{\mathrm{plant}}=\delta^{13} \mathrm{C}_{\mathrm{air}}-a-(b-a)\left(C_{i} / C_{a}\right),
$$

where $a$ is the discrimination caused by diffusion of $\mathrm{CO}_{2}$ through the stomata and $b$ is the discrimination resulting from $\mathrm{CO}_{2}$ fixation by ribulose-1, 5-biphosphate carboxylase-oxygenase and are considered constants. The term $C_{i} / C_{a}$ is the ratio of the partial pressures of intercellular $\mathrm{CO}_{2}$ to atmospheric $\mathrm{CO}_{2}$ and is a function of stomatal conductance and carbon assimilation rate. This ratio is sensitive to environmental parameters, such as water stress, humidity, light levels, temperature, nutrients and $\mathrm{pCO}_{2}$ (McCarroll and Loader 2004).

Arens et al (2000) have compiled a large database $(n=394)$ to assess the effect of $C_{i} / C_{a}$ and $\delta^{13} \mathrm{C}_{\text {air }}$ on plant $\delta^{13} \mathrm{C}$. They found that when some of the environmental parameters, such as light condition, nutrients and temperature are low, the $C_{i} / C_{a}$ ratio increases resulting decrease in 
$\delta^{13} \mathrm{C}_{\text {plant }}$. On the other hand, water stress and low relative humidity, osmotic stress decrease the $C_{i} / C_{a}$ ratio, thereby increasing the plant $\delta^{13} \mathrm{C}$. Over geological timescales, when the atmospheric $\mathrm{CO}_{2}$ concentration varies significantly, the dominant control on $\delta^{13} \mathrm{C}_{\text {plant }}$ is the carbon isotopic ratio of the atmospheric $\mathrm{CO}_{2}$ (op cit.). Although Gröcke (1998) has observed an inverse relationship between $\delta^{13} \mathrm{C}_{\text {plant }}$ and $\mathrm{pCO}_{2}$, Arens et al (2000) demonstrate that $90 \%$ of plant $\delta^{13} \mathrm{C}$ variations can be accounted for, by the isotopic composition of the atmospheric $\mathrm{CO}_{2}$. Hence they establish the following relationship between $\delta^{13} \mathrm{C}_{\text {air }}$ and $\delta^{13} \mathrm{C}_{\text {plant }}$ :

$$
\delta^{13} \mathrm{C}_{\text {plant }}=1.10 \times \delta^{13} \mathrm{C}_{\text {air }}-18.67 .
$$

In deriving this equation the authors did not use fossil plants, rather plants were grown in chambers that simulated the past atmospheric conditions. The air $\delta^{13} \mathrm{C}$ was varied between -6 and $-10 \%$ while $\mathrm{pCO}_{2}$ had a range of 98 to $1300 \mathrm{ppmV}$. The $\delta^{13} \mathrm{C}_{\text {plant }}$ was observed to have varied from -20 to $-36 \%$. According to Arens et al (2000) this equation can be applied in the case of fossil plants, when the $\mathrm{pCO}_{2}$ was significantly higher than today, to estimate the past value of atmospheric $\delta^{13} \mathrm{C}_{\text {air }}$. Until recently it is believed that the atmospheric $\mathrm{CO}_{2}$ concentration during the Early Aptian was about $1470 \mathrm{ppmV}$ (Berner and Kothavala 2001). However, a recent study reports that the atmospheric $\mathrm{pCO}_{2}$ was in the range of $1130 \mathrm{ppmV}$ (Fletcher et al 2008) in the Early Cretaceous (ca. $100 \mathrm{Ma}$ ago). This value lies within the $\mathrm{pCO}_{2}$ range of $98-1300 \mathrm{ppmV}$ used by Arens et al (2000) to derive equation (2). Hence we use this equation to determine the atmospheric $\delta^{13} \mathrm{C}$ using the fossil leaf $\delta^{13} \mathrm{C}$ values.

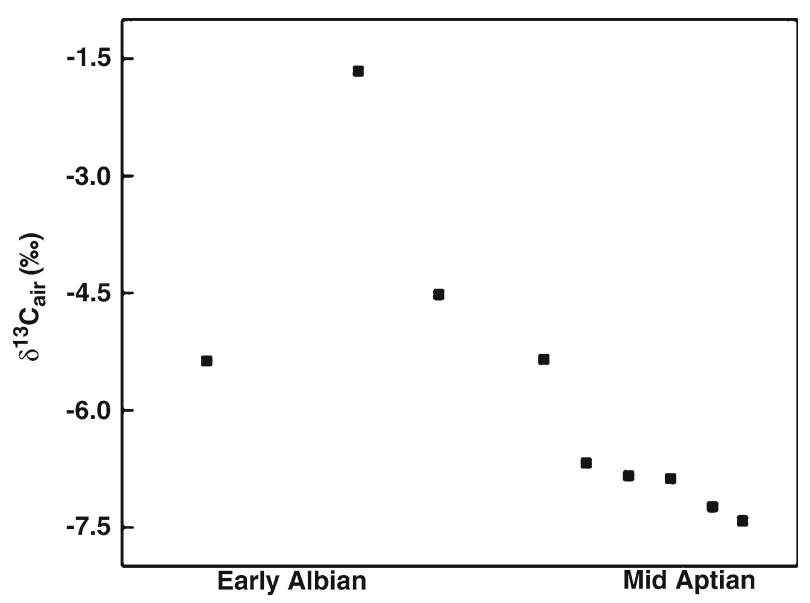

Figure 4. Determination of the atmospheric $\delta^{13} \mathrm{C}$ based on the carbon isotopic composition of the fossil leaves from the Kachchh basin during the Aptian-Albian using the equation derived by Arens et al (2000). Method of calculation is given in the text.
Figure 4 plots the atmospheric carbon isotopic composition during the Early Cretaceous. The atmospheric $\delta^{13} \mathrm{C}$ increased from $-7.4 \%$ from lower Aptian to about $-1.7 \%$ in the upper Aptian. During this time the atmospheric $\mathrm{pCO}_{2}$ value decreased from $1500 \mathrm{ppmV}$ to about $1300 \mathrm{ppmV}$ (Royer et al 2001). The atmospheric $\delta^{13} \mathrm{C}$ values derived here agree with the estimates of Berner (1991), except one of the Mathal samples that had $\delta^{13} \mathrm{C}$ of $-1.7 \%$; this is in contrast to the values given by Gröcke (2002) who estimated an average atmospheric $\delta^{13} \mathrm{C}$ to be in the order of $-3 \%$ during the Aptian.

We have also estimated the $C_{i} / C_{a}$ ratio for these plants using equation (1) and time series of atmospheric $\delta^{13} \mathrm{C}$ were generated for a set of values of $C_{i} / C_{a}$ (ranging from 0.6 to 0.7 ) and are shown in figure 5 assuming that this ratio remained constant throughout the Early Cretaceous. This assumption is justified since within reasonable limits plants tend to maintain a constant $C_{i} / C_{a}$ ratio to optimize their assimilation rate. This was demonstrated for some modern plants which maintained a nearly constant $C_{i} / C_{a}$ ratio despite a moderate increase in atmospheric $\mathrm{pCO}_{2}$ (Francey and Farquhar 1982). The values of $a$ and $b$ (in equation 1 ) are taken to be 4.4 and $27 \%$, respectively. These values are typical for $\mathrm{C}_{3}$ plants (Farquhar et al 1982b). The lowermost curve in this figure correspond to $C_{i} / C_{a}=$ 0.6 and the uppermost curve to 0.7 . The plot corresponding to $C_{i} / C_{a}=0.65$ closely resembles the values reconstructed earlier using equation (2) (grey line in figure 5 ). The value 0.65 is comparable to

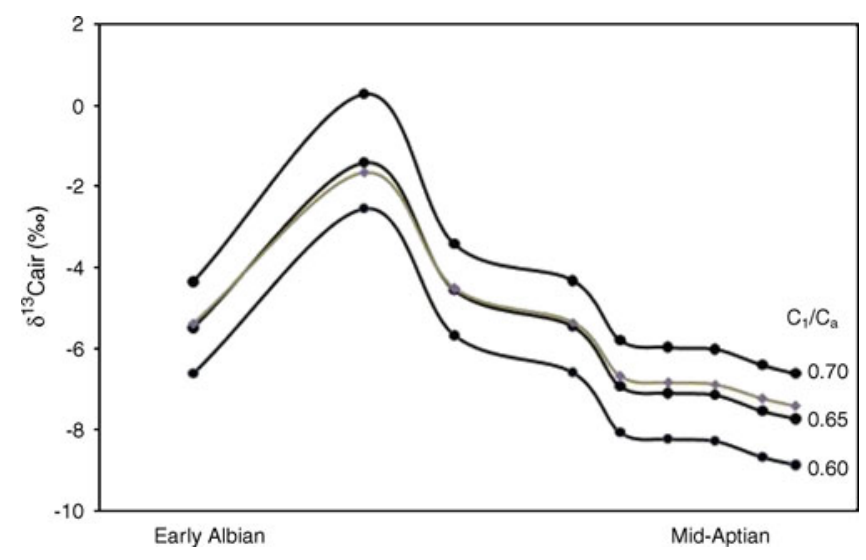

Figure 5. Numerical estimation of $\delta^{13} \mathrm{C}$ of the Aptian air based on the fractionation model of Farquhar et al (1982a) for $\mathrm{C}_{3}$ plants (equation 1 in the text). Time series of air $\delta^{13} \mathrm{C}$ were generated using the plant isotopic values and for given values of $C_{i} / C_{a}$, i.e., $0.6,0.65$ and 0.7 , respectively (bottom to top). Then these time series were compared with the air $\delta^{13} \mathrm{C}$ derived using equation (2), represented by grey line in this figure. Air $\delta^{13} \mathrm{C}$ time series with $C_{i} / C_{a}=0.65$ appears to have good match with the observed data. 
that of many modern $\mathrm{C}_{3}$ plants that are characterized by a value of 0.7 (Evans et al 1986; Polley et al 1993). This implies that the (Early Cretaceous) plants modulated their $C_{i}$ in response to a high $C_{a}$ value at that time (the average $\mathrm{pCO}_{2}$ during the Aptian was $\sim 1100-1200$ ppmV, i.e., Fletcher et al 2008) probably by increasing their photosynthetic rate aided by the prevailing higher temperature since photosynthetic capacity of a plant increases with temperature (Amthor 1995; Beerling 1996).

\section{Conclusions}

The carbon isotopic composition of plant fossils from the western India is used to estimate the isotopic composition of atmospheric carbon dioxide during the Aptian-Albian using a recently established empirical model. The $\delta^{13} \mathrm{C}$ of the fossil leave showed similar pattern of variation with that of the bulk rock carbon isotopic composition that represented the carbon cycle perturbation in the ocean atmospheric system. The atmospheric $\delta^{13} \mathrm{C}$ progressively increased from $c a$. -7.4 to about $-1.7 \%$ o and then reduced to $c a$. $-5.4 \%$ from the Mid Aptian to Early Albian. This result accords well with the decreasing trend in $\mathrm{pCO}_{2}$ observed over this period and with the estimate of Cerling (1991). Based on a leaf $\mathrm{CO}_{2^{-}} \delta^{13} \mathrm{C}_{\text {air }}$ fractionation model, the plant $C_{i} / C_{a}$ ratio of $\mathrm{C}_{3}$ plants during the Aptian-Albian is estimated to be similar to that of the modern plants. This indicates that the Early Cretaceous plants seem to have adapted themselves to the prevailing high $\mathrm{pCO}_{2}$ regime by increasing their photosynthetic uptake.

\section{Acknowledgements}

SC is grateful to Prof. B N Goswami, Director IITM for his encouragement. The comments and criticisms by the two anonymous reviewers are thankfully acknowledged. The authors thank Prof. R Ramesh, PRL, Ahmedabad for his comments that improved the quality of the paper.

\section{References}

Amthor J S 1995 Terrestrial higher plant response to increasing atmospheric $\left[\mathrm{CO}_{2}\right]$ in relation to the global carbon cycle; Global Change Biology 1 243-274.

Arens N C, Jahren A H and Amundson R 2000 Can $\mathrm{C}_{3}$ plants faithfully record the carbon isotopic composition of the atmospheric carbon dioxide? Palaeobiology 26(1) $137-164$.
Aucourt A M and Hillaire-Marcel C 1993 A 30,000 years record of ${ }^{13} \mathrm{C}$ and ${ }^{18} \mathrm{O}$ changes in organic matter form an equatorial peatbog; In: Climate change in Continental Isotopic Records (eds) Swart P K, Lohmann K C, McKenzie J and Savin S, Geophys. Monogr. Am. Geophys. Union, pp. 343-351.

Beerling D J $1996{ }^{13} \mathrm{C}$ discrimination by fossil leaves during the late-glacial climate oscillation 12-10 ka BP: Measurements and physical controls; Oecologia 108 29-37.

Berner R A 1991 A model for atmospheric $\mathrm{CO}_{2}$ over Phanerozoic time; Am. J. Sci. 291 339-376.

Berner R A and Kothavala Z 2001 Geocarb III: A revised model of atmospheric $\mathrm{CO}_{2}$ over Phanerozoic time; $\mathrm{Am}$. J. Sci. 301 182-204.

Bocherens H and Marootti A 1998 Carbon stable isotope analysis of fossil plants; In: Fossil plants and spores: Modern techniques (eds) Jones T P and Rowe N P, Geol. Soc. Spec. Publ. London, pp. 80-100.

Bose M N and Roy S K 1961 Studies in the Upper Gondwana Kutch - 2. Isoetaceae; Palaeobotanist 12 226-228.

Bose M N and Kasat M L 1972 The genus Ptilophyllum in India; Palaeobotanist 19 115-145.

Bose M N and Banerji J 1984 The fossil floras of Kachchh. I - Mesozoic megafossils; Palaeobotanist 33 1-189.

Bralower T J, Arthur M A, Leckie R M, Sliter W V, Allard D J and Schlanger S O 1994 Timing and paleocenography of oceanic dysoxia/anoxia in the Late Barremian to Early Aptian (Early Cretaceous); Palaios 9 335-369.

Cerling T E 1991 Carbon dioxide in the atmosphere: Evidence from Cenozoic and Mesozoic paleosols; Am. J. Sci. $291377-400$.

Coplen T B, Brand W A, Gehre M, Gröning M, Meijer H A J, Toman B and Verkouteren R M 2006 After two decades a second anchor for the VPDB $\delta^{13} \mathrm{C}$ scale; Rapid Comm. Mass Spectrom. 20 3165-166.

Crane P R, Friis E M and Pedersen K R 1995 The origin and early diversification of angiosperm; Nature 374 27-33.

Degens E T 1969 Biogeochemistry of stable carbon isotopes; In: Organic Geochem. Methods and Research (eds) Eglington G and Murphy M T (Berlin: Springer), pp. 304-329.

Evans J R, Sharkey T D, Berry J A and Farquhar G D 1986 Carbon isotopic discrimination measured concurrently with gas exchange to investigate $\mathrm{CO}_{2}$ diffusion in leaves of higher plants; Aust. J. Plant Physiol. 13 281-292.

Farquhar G D, O'Leary M H and Berry J A 1982a On the relationship between carbon isotope discrimination and the intercellular carbon dioxide in leaves; Aust. J. Plant Physiol. 9 121-137.

Farquhar G D, O'Leary M H and Berry J A 1982b Effect of salinity and humidity on $\delta^{13} \mathrm{C}$ value of halophytes: Evidence for diffusional isotope fractionation determined by the ratio of intercellular/atmospheric partial pressure of $\mathrm{CO}_{2}$ under different environmental conditions; Oecologia 52 121-124.

Fletcher B J, Brentnall S J, Anderson C W, Berner R A and Beerling D J 2008 Atmospheric carbon dioxide linked with Mesozoic and early Cenozoic climate change; Nature Geosci. 1 43-48.

Francey R J and Farquhar G D 1982 An explanation of ${ }^{13} \mathrm{C} /{ }^{12} \mathrm{C}$ variations in tree rings; Nature $29728-31$.

Francey R J, Allison C E, Etheridge D M, Trudinger C M, Enting I G, Leuenberger M, Langenfelds R L, Michel E and Steele L P 1999 A 1000-year high precision record of $\delta^{13} \mathrm{C}$ in atmospheric $\mathrm{CO}_{2}$; Tellus 51B $170-193$.

Gröcke D R 1998 Carbon isotope analyses of fossil plant as a chemostratigraphic and paleoenviromental tool; Lethaia 31 1-13. 
Gröcke D R 2002 The carbon isotopic composition of ancient $\mathrm{CO}_{2}$ based on higher plant organic matter; Phil. Trans. Roy. Soc. London Ser. A $360633-658$.

Gröcke D R, Hesselbo S P and Jemkyns H C 1999 Carbonisotope composition of Lower Cretaceous fossil wood: Ocean-atmosphere chemistry and relation to sea-level change; Geology 27(2) 155-158.

Grocke D R, Price G D, Robinson S A, Baraboshkin E Y, Mutterlose J and Ruffel A H 2005 The Upper Valanginian (Early Cretaceous) positive carbon-isotope event recorded in terrestrial plants; Earth Planet. Sci. Lett. 240 495-509.

Hasegawa T, Pratt L M, Maeda H, Shigeta Y, Okamoto T, Kase T and Uemura K 2003 Upper Cretaceous stable carbon isotope stratigraphy of terrestrial organic matter from Sakhalin, Russian Far East: A proxy for the isotopic composition of paleoatmospheric $\mathrm{CO}_{2} ;$ Paleogeogr. Palaeoclimatol. Palaeoecol. 189 97-115.

Heaton T H E 1999 Spatial, species, and temporal variations in the ${ }^{13} \mathrm{C} /{ }^{12} \mathrm{C}$ ratios of $\mathrm{C}_{3}$ plants: Implications for palaeodiet studies; J. Archaeol. Sci. 26 637-649.

Jemkyns H C 1980 Cretaceous anoxic events: From continents to oceans; J. Geol. Soc. London 137 171-188.

Knöller K, Boettger T, Weise S M and Gehre M 2005 Carbon isotope analyses of cellulose using two different online techniques (elemental analysis and high-temperature pyrolysis) - a comparison; Rapid Comm. Mass Spectrom. $19343-348$.

Littler K, Robinson S A, Bown P R, Nederbragt A J and Pancost R D 2011 High sea-surface temperatures during the Early Cretaceous Epoch; Nature Geosci. 4 169-172.

Leavitt S W and Long A 1986 Stable-carbon isotope variability in tree foliage; Wood. Eco. 67(4) 1002-1010.

Leavitt S W and Newberry T 1992 Systematics of stablecarbon isotopic differences between gymnosperm and angiosperm trees; Plant Physiol. (Life Sci. Adv.) 11 $257-262$.

Leuenberger M, Siegenthaler U and Langway C C 1992 Carbon isotope composition of atmospheric $\mathrm{CO}_{2}$ during the last ice age from an Antarctic ice core; Nature $\mathbf{3 5 7}$ 488-490.

Lockheart M J, Poole I, Van Bergen P F and Evershed R P 1998 Leaf carbon isotope compositions and stomatal characters: Important considerations for palaeoclimate reconstructions; Org. Geochem. 29(4) 1003-1008.

McCarroll D and Loader N J 2004 Stable isotope is tree rings; Quat. Sci. Rev. 23 771-801.

Minagawa M, Winter D A and Kaplan I R 1984 Comparison of Kjeldahl and combustion methods for measurement of nitrogen isotope ratios in organic matter; Anal. Chem. 56 1859-1861.

Nambudiri E V M, Tidwell W D, Smith B N and Hebber N P 1978 A C4 plant from the Pliocene; Nature 276 816-817.
Polley H W, Johnson H B, Marin B D and Mayeux H S 1993 Increase in $\mathrm{C}_{3}$ plant water use efficiency and biomass over Glacial to present $\mathrm{CO}_{2}$ concentrations; Nature 361 61-64.

Popp B N, Takigiku R, Hayes J M, Louda J W and Baker E W 1989 The post-Paleozoic chronology and mechanism of ${ }^{13} \mathrm{C}$ depletion in primary marine organic matter; $\mathrm{Am}$. J. Sci. 289 436-454.

Retallack G J 2001 A 300 million year record of atmospheric carbon dioxide from fossil plant cuticles; Nature $\mathbf{4 1 1}$ $287-290$.

Rigby D, Batts B D and Smith J W 1981 The effect of maturation on the isotopic of fossil fuels; Org. Geochem. $329-36$.

Roy S K 1967 Ptilophyllum horridum sp. from Trambau, Kutch; Curr. Sci. 36 581-582.

Royer D L, Berner R A and Beerling D 2001 Phanerozoic atmospheric $\mathrm{CO}_{2}$ change: Evaluating geochemical and paleobiologcial approaches; Earth Sci. Rev. 54 349-392.

Rozanski K 1991 Consultants' Group Meeting on C-14 reference materials for radiocarbon laboratories, IAEA, Vienna, 18-20 February 1991; Report to the Director General, IAEA, Vienna, 54 pp.

Rozanski K, Stichler W, Gonfiantini R, Scott E M, Beukens R P, Kromer B and Van der Plicht J 1992 The IAEA ${ }^{14} \mathrm{C}$ inter-comparison exercise 1990; Radiocarbon 34(3) $506-519$.

Sahni B 1928 Revision of Indian Fossil plants pt. I. Coniferales (a. Impressions and incrustations); Geological Survey of India Memoir; Palaeont. Indica 11 1-49.

Saraswati P K and Ramesh R 1992 Eocene-Oligocene stable isotope stratigraphy of Kutch; J. Geol. Soc. India 39 427432 .

Saraswati P K, Ramesh R and Navada S V 1993 Palaeogene isotopic temperatures in western India; Lethaia 26 89-98.

Seward A C and Sahni B 1920 Indian Gondwana Plants. A revision; Geol. Surv. India Memoir; Palaeont. Indica 7 $1-41$.

Sofer Z 1980 Preparation of carbon dioxide for stable carbon isotope analysis of petroleum fractions; Anal. Chem. 52 1389-1391.

Turney C S M, Hunt J E and Burrows C 2002 Deriving a consistent $\delta^{13} \mathrm{C}$ signature from tree canopy leaf material for palaeoclimatic reconstruction; New Phytologist 155 301-311.

Vogel J C 1980 Fractionation of the carbon isotopes during photosynthesis; In: Sitzungsberichte der Heidelberger Akademie der Wissenschaften (Berlin: Springer-Verlag) pp. 111-135.

Wiessert $\mathrm{H}$ and Erba E 2004 Volcanism, $\mathrm{CO}_{2}$, and palaeoclimate: A Late Jurassic-Early Cretaceous carbon and oxygen isotope record; J. Geol. Soc. London 161 695-702. 